\section{Water Conservation Team in Ornamental Crops through the Use of Alternative Irrigation Water Sources}

\author{
Genhua Niu ${ }^{1,4}$, Raul I. Cabrera ${ }^{2}$, Terri W. Starman ${ }^{3}$, \\ and Charles R. Hall ${ }^{3}$
}

AdDitional INDEX wORDs. landscape plants, salinity tolerance, water reuse

\section{Significance and objectives}

Many communities in Texas and other states are facing water shortages and water quality issues (poor or marginal water quality). A tremendous population growth in many southern states is also putting a strain on their water supplies and creating a worrisome competition between urban and agricultural activities. Future drought is unpredictable, and some regions have encountered extended and devastating drought periods in the past years. In addition, intensive agricultural operations like nurseries and greenhouses are under pressure to conserve water and minimize fertilizer- and chemical-laden water drainages and runoff effluents (Briggs et al., 1998; Cabrera, 2005; Camper et al., 1994). Water availability and water quality issues are getting worse over time and are significantly affecting the future of green industries (greenhouse, nursery, landscape).

Water conservation can be achieved by irrigating greenhouse and nursery crops, and landscape plantings with alternative water sources, thus saving the dwindling clean/fresh water for other purposes. Low-maintenance plant species that are drought and salt tolerant would be desirable for green industry. The types of available alternative or nonpotable water sources vary with regions. Reclaimed municipal water is often the main alternative water. In some places, saline groundwater and

\footnotetext{
This paper was part of the National Floriculture Forum, "Partnerships, Alliances, Brands and Initiatives," held 10-11 Mar. 2011 in Dallas, TX, and hosted by Texas A\&M University.

${ }^{1}$ AgriLife Research and Extension Center at El Paso, Texas A\&M System, 1380 A\&M Circle, El Paso, TX 79927

${ }^{2}$ AgriLife Research and Extension Center at Dallas, Texas A\&M System, 17360 Coit Road, Dallas, TX 75252

${ }^{3}$ Department of Horticulture, Texas A\&M University, College Station, TX 77843

${ }^{4}$ Corresponding author. E-mail: gniu@ag.tamu.edu.
}

agricultural drainage water are available. The salinity of reclaimed water measured as electrical conductivity $\left(\mathrm{EC}_{\mathrm{w}}\right)$, which varies with water source and treatment processes, ranges from 1.0 to $1.9 \mathrm{dS} \cdot \mathrm{m}^{-1}$ (Schuch, 2005; Wu et al., 2001). To successfully use these alternative water sources, information on salt tolerance of economically important ornamental plants and their salinity thresholds are needed.

\section{Nature of partnerships, alliances, brands, and initiatives}

Our team at the Texas A\&M University (TAMU) System is addressing water quantity and quality issues and needs through cooperative research, teaching, and extension programs. In the past few years, our research activities have focused on salt tolerance screening and water use determination of many ornamental crops. The identification of salinity thresholds of ornamental plants will allow for the use of specific alternative water source in nursery and greenhouse operations, and urban landscapes. The water use and crop coefficient data of ornamental plants will help nursery industry, landscape professionals, and homeowners to increase irrigation efficiency by scheduling irrigation timing and determining irrigation amount more attuned to real plant needs (Niu et al., 2006).

Water is also one of the priority areas stated in the strategic plan for the Ellison Chair in International Floriculture at TAMU. One of the first activities of the current holder of the chair was to develop a comprehensive website that compiles many of the resources regarding water best management practice, conservation practices, water auditing tools, Texas and U.S. policy resources, and detailed information regarding the Clean Water Act (TAMU, 2011).

We are grateful to receive the financial support from federal, state, and local agencies and industries. The Federal Rio Grande Basin Initiative (RGBI), administrated through U.S. Department of Agriculture (USDA), National Institute of Food and Agriculture (NIFA), and the Texas Water Research Institute and New Mexico State University, has supported targeted research and extension activities in the basin since 2001 . We have received funding from RGBI for "urban landscape water conservation" (Task 5) and "saline and wastewater management and water reuse" (Task 7) to support our research and extension activities on salt tolerance and water conservation of ornamental plants. The Texas Water and Development Board, Texas Nursery and Landscape Association, International Cut Flower Growers Association, Joseph H. Hill Foundation, Texas Department of Agriculture's Specialty Crops Program, El Paso Water Utilities, and several greenhouse and nursery firms have also provided support for our activities.

For our future research and extension efforts, we are continuing our effort in water conservation related to the green industry. For example, a PhD graduate student (A. Cai), supported by T. Starman, G. Niu, and C. Hall, is working on drought and salt tolerance of landscape plants, mainly garden roses. Niu is a co-principal investigator on a USDA-NIFA Specialty Crops Research Initiative grant, "Impact and social acceptance of selected sustainable practices in ornamental crop production systems," in which she will evaluate the sustainability of plastic container alternatives for use in nursery production systems and determine the impact of biocontainers on water use of nursery crops and the impact on landscape performance. R. Cabrera is leading research projects on the characterization of daily and seasonal nutrient and water use and

\begin{tabular}{llll}
\hline $\begin{array}{l}\text { Units } \\
\begin{array}{l}\text { To convert U.S. to SI, } \\
\text { multiply by }\end{array}\end{array}$ & U.S. unit & SI unit & $\begin{array}{l}\text { To convert SI to U.S., } \\
\text { multiply by }\end{array}$ \\
\hline $\mathrm{l}$ & $\mathrm{mmho} / \mathrm{cm}$ & $\mathrm{dS} \cdot \mathrm{m}^{-1}$ & $\mathrm{l}$
\end{tabular}


patterns by greenhouse roses, and the effect of localized root-zone water/ nutritional stresses on rose flower productivity and quality. These projects have been financially supported by the International Cut Flower Growers Association (through the J.H. Hill Foundation), plus gracious in-kind donations and advice from key growers in California and Colombia. Another water-related research project pertains to the estimation of water and nutrient use in mistletoe-infested landscape/ street trees, in particular, assessing the impact of the semiparasitic american mistletoe (Phoradendron spp.) on the water economy of the trees and their surrounding urban landscapes.

\section{Available information on salt tolerance of ornamental plants}

Our major research results are published in HortScience (Niu and Cabrera, 2010; Niu and Rodriguez, 2006a; Niu et al., 2010), Journal of American Society for Horticultural Science (Niu and Rodriguez, 2008, 2009), HortTechnology (Niu et al., 2007b), Journal of Environmental Horticulture (Niu et al., 2007a, 2007c), and Scientia Horticulturae (Niu and Rodriguez, 2006b). Niu and Cabrera (2010) provided a summary of their work on growth and physiological responses of ornamental plants to saline water irrigation. In addition, the National Water Research Institute provides a database on salinity management guidelines for landscapes irrigated with recycled water (reclaimed water) (National Water Research Institute, 2011), including quality of recycled water, management of root-zone salinity, plant selection, and irrigation system. Since thousands of cultivars of ornamental plants are used in landscapes, further research on salt tolerance of plants species with unknown responses to salt stress is needed.

\section{Literature cited}

Briggs, J.A., M.B. Riley, and T. Whitwell. 1998. Quantification and remediation of pesticides in runoff water from containerized plant production. J. Environ. Qual. 27:814-820.

Cabrera, R.I. 2005. Challenges and advances in water and nutrient management in nursery and greenhouse crops. Agricoltura Mediterranea 135:147-160.

Camper, N.D., T. Whitwell, R.J. Keese, and M.B. Riley. 1994. Herbicide levels in nursery containment pond water and sediments. J. Environ. Hort. 12:8-12.

National Water Research Institute. 2011. Salinity management guide. 22 Mar. 2011. $<$ http://www.salinitymanagement.org/>.

Niu, G. and R.I. Cabrera. 2010. Growth and physiological responses of landscape plants to saline water irrigation. HortScience 45:1605-1609.

Niu, G. and D. Rodriguez. 2006a. Relative salt tolerance of five herbaceous perennials. HortScience 41:1493-1497.

Niu, G. and D. Rodriguez. 2006b. Relative salt tolerance of selected herbaceous perennials and groundcovers. Sci. Hort. 110:352-358.

Niu, G., D. Rodriguez, R. Cabrera, C. McKenney, and W. Mackay. 2006. Determining water use and crop coefficients of five woody landscape plants. J. Environ. Hort. 24:160-165.
Niu, G. and D.S. Rodriguez. 2008. Responses of growth and ion uptake of four rose rootstocks to chloride or sulfate dominated salinity. J. Amer. Soc. Hort. Sci. 133:633-669.

Niu, G. and D.S. Rodriguez. 2009. Growth and physiological responses of four rose rootstocks to drought stress. J. Amer. Soc. Hort. Sci. 134:202-209.

Niu, G., D.S. Rodriguez, and L. Awuinga. 2007a. Growth and landscape performance of ten herbaceous species in response to saline water irrigation. J. Environ. Hort. 25:204-210.

Niu, G., D.S. Rodriguez, and W. Mackay. 2007b. Effect of water stress on growth and flower yield of big bend bluebonnet. HortTechnology 17:557-560.

Niu, G., D.S. Rodriguez, and T. Starman. 2010. Response of bedding plants to saline water irrigation. HortScience 45: 628-636.

Niu, G., D.S. Rodriguez, and Y.T. Wang. $2007 \mathrm{c}$. Salinity and growing medium regulate growth, morphology and ion uptake of Gaillardia aristata. J. Environ. Hort. 25:89-94.

Schuch, U. 2005. Effect of reclaimed water and drought on salt-sensitive perennials. HortScience 40:1095. (Abstr.).

Texas A\&M University. 2011. Ellison Chair in International Floriculture. Water Resources. 22 Mar. 2011.<http:// ellisonchair.tamu.edu/emphasis-areas/ water-resources $/>$.

Wu, L., X. Guo, and A. Harivandi. 2001. Salt tolerance and salt accumulation of landscape plants irrigated by sprinkler and drip irrigation systems. J. Plant Nutr. 24: 1473-1490. 